\section{The effect of different distance of curing light and ceramic materials on microhardness of the resin}

\section{Farklı ısınlama mesafelerinin ve seramik materyallerinin rezin simanın yüzey sertliği üzerine etkisinin incelenmesi}

\author{
Assist. Prof. Dr. Ayse ATAY \\ Bezmialem University, Faculty of Dentistry, \\ Department of Prosthodontics, Istanbul \\ Dt. Işıl GÜRDAL \\ Bezmialem University, Faculty of Dentistry, \\ Department of Prosthodontics, Istanbul
}

\section{Dr. Simge TAŞIN}

Okan University, Faculty of Dentistry, Department of

Prosthodontics, Istanbul

Assist. Prof. Dr. Özlem KARA

Bezmialem University, Faculty of Dentistry,

Department of Prosthodontics, İstanbul

Prof. Dr. Aslıhan ÜŞÜMEZ

Private Practise, Istanbul

Received: 11 March 2017

Accepted: : 4 September 2017

doi: 10.5505/yeditepe.2017. 84856

\section{Corresponding author:}

Assist. Prof. Dr. Ayse ATAY

Bezmialem University, Faculty of Dentistry,

Department of Prosthodontics, İstanbul

Phone: +90-212-4531700 Fax: +90-212-4531873

E-mail: ayseatay82@hotmail.com,

aatay@bezmialem.edu.tr

\section{SUMMARY}

Aim: The aim of this study was to evaluate the effect of different curing distances and ceramic materials on the microhardness of dual-cured resin cement.

Materials and Methods: The dual-cured resin cement (NX3, Kerr) was polymerized between between lithium disilicate based pressed ceramic (IPS e.max Press (EP)), or three different CAD/CAM materials (Lava Ultimate (LU), e.max CAD (EC), Vita Suprinity (VS)) and a dentine surface with a LED light source from 0,3 or $6 \mathrm{~mm}$ distances for 10 seconds $(n=10)$. The Vickers microhardness (VH) values were recorded immediately after polymerization and after storage at dark in distilled water $\left(24 \mathrm{~h} / 37^{\circ} \mathrm{C}\right)$. Three indentations were made both on the top and the bottom surface of each specimen. ANOVA was used to analyse the data. Bonferroni test was used to perform multiple comparisons $(p<0.05)$.

Results: The resin cements under the LU specimens have significantly higher $\mathrm{VH}$ values compared to the other materials $(p<0.05)$. The bottom surfaces have significantly lower hardness values for all ceramic materials $(p<0.05)$. The VH value of $0 \mathrm{~mm}$ curing tip-ceramic distance was significantly higher than the groups of 3 and $6 \mathrm{~mm}$ distances $(\mathrm{p}<0.05)$. Microhardness values were significantly higher after 24 hours than immediate measurement $(p<0.05)$.

Conclusion: Ceramic material and the curing tip-ceramic distance are important factors to be considered for obtaining adequate polymerization.

Keywords: CAD/CAM, microhardness, ceramic materials, distance of curing tip

\section{ÖZET}

Amaç: Bu çalışmanın amacı, ışık kaynağı ile seramik materyalleri arasındaki farklı ısınlama mesafelerinin kullanılan rezin simanın yüzey sertliğine etkisinin incelenmesidir.

Gereç ve Yöntem: Dual-cure rezin siman (NX3, Kerr), lityum disilikat press seramik (IPS e.max Press (EP)) veya 3 farklı CAD/CAM materyali (Lava Ultimate (LU), e.max CAD (EC), Vita Suprinity (VS)) ile dentin yüzeyi arasında, LED ışık cihazı kullanılarak 10 sn boyunca 0,3 ve $6 \mathrm{~mm}$ mesafelerden polimerize edildi $(n=10)$. Örneklerin Vickers sertlik değerleri, polimerizasyondan hemen sonra ve karanlık ortamda, $37^{\circ} \mathrm{C}^{\prime}$ de 24 saat distile suda bekletildikten sonra yapıldı. Her örneğin alt ve üst yüzeylerinden üç noktadan ölçüm yapıldı. Verilerin analizi ANOVA ile yapıldı. Çoklu karşılaştırmalar için Bonferroni testi kullanıldı $(p<0,05)$.

Bulgular: LU örneklerin altındaki rezin simanın sertlik değerleri, diğer materyallere oranla istatistiksel olarak anlamlı derecede yüksek bulundu $(p<0,05)$. Tüm gruplarda alt yüzeyin sertlik değerleri üst yüzeye göre anlamlı düzeyde düşük bulundu $(p<0,05)$. Işık kaynağı - seramik arası mesafenin $0 \mathrm{~mm}$ olduğu grupların sertlik değerleri, 3 ve $6 \mathrm{~mm}$ olan gruplara göre anlamlı düzeyde yüksek bulundu $(p<0,05) .24$ saat sonraki ölçümlerde elde edilen sertlik değerleri, polimerzason- 
dan hemen sonra yapılan ölçümlerdeki değerlere göre anlamlı olarak yüksek bulundu $(p<0,05)$.

Sonuç: Yeterli polimerizasyon elde edebilmek için kullanılan seramik materyalinin ve ışık kaynağı ile mesafesinin önemli faktörler olduğu sonucuna varıldı.

Anahtar kelimeler: CAD/CAM, yüzey sertliği, seramik materyalleri, ışınlama mesafesi

\section{INTRODUCTION}

Among the dental materials, the ceramics have the closest optical properties to natural tooth and they are frequently used for aesthetic restorations. ${ }^{1}$ Nowadays, most of these restorations can be produced by both traditional methods and Computer-aided design/Computer-aided manufacturing (CAD/CAM) systems. ${ }^{2,3} \mathrm{CAD} / \mathrm{CAM}$ systems were brought into use of dentistry during 1980's. For the last ten years, CAD/CAM has gained great significance and popularity. ${ }^{4}$ Lately it has become more accurate, faster, less expensive and easier to use. Because the restoration can be fabricated in only one visit; impressions, provisional restorations, extra materials and helping staff is not needed, which saves time both for patients and dentists. Different parameters like the shape, thicknesses of the restoration and cement can easily be controlled. The data can be saved and used for fabricating the restoration later again. The use of industrial blocks enables the manufacture of high strength restorations that are more reliable. ${ }^{5,6}$

The first CAD/CAM restoration was produced in 1985 as an inlay made of fine grain feldspathic ceramic (Vita Mark 1, Vita Zahnfabrik, Bad Sackingen, Germany). ${ }^{7}$ There are CAD/CAM blocks containing glass ceramics, feldspathic glass ceramics, lithium disilicate glass ceramics, leucite-reinforced glass ceramics, aluminum-oxide and yttrium tetragonal zirconia polycrystals, composite resin and titanium which is usually used for implant abutments. ${ }^{4}$ Latest dental technology has produced a newly developed nano/hybrid ceramic material that is composed of a polymer network integrated into the ceramic structure. 8,9 The first composite resin block which was introduced in 2000, was polymerized by light activation from factory processes. ${ }^{7}$ These materials aim to gather ceramics' advantages and resin materials' properties together. Ceramic percentage differs in weight between $80-86 \%$ and the polymer weight differs between 14-20\%. Ceramic structures and resin polymers are processed at high temperatures with special techniques.8,9 Another material that is recently developed and launched is the lithium silicate ceramics reinforced by zirconia. These materials aim to have both the superior mechanical properties of zirconia and the optical behaviour of glass ceramics. The zirconia-reinforced lithium silicate (Vita Suprinity) contains 56-64\%SiO2, 15-21\%Li2O, 8-12\%ZrO2, 3-8\%P2O5,
1-4\%K2O, 1-4\%AB2O3, 0-4\%CeO2 and 0-6\%colour pigments. It gains its final physical and aesthetic properties after the crystallisation in dental furnaces. ${ }^{10}$

Restorations as inlays, onlays, laminate veneers and all ceramic crowns that does not contain metal, are generally luted with dual cured resin cements because of the reduced light transmission through the restoration. ${ }^{11}$ Dual cured resin cement ensures a complete chemical reaction and a full degree of conversion (DC). During adhesive cementation ceramic type, thickness, translucency, the type of the light source and the distance between curing unit light guide and cement layer have an effect on the polymerization of the resin luting cement. ${ }^{12}$ The transmission of light through a restoration influences the polymerisation of the underlying resin cement. ${ }^{13}$ The mechanical properties and biocompatibility of resin cements largely depend on their ratio of monomer conversion. ${ }^{12,14}$ The degree of polymerization of the resin matrix also affects the hardness of the material. The hardness of the surface is one of the most significant physical properties of a dental material and it can be defined as the resistance of a material to indentation or penetration. ${ }^{14,15}$ Testing the hardness of a material is also a frequently used method for estimating the DC of a resin based material. ${ }^{16}$ The top and the bottom surfaces of the resin material do not receive the same amount of light from the curing unit. Price ${ }^{17}$ suggest that the difference between the top and the bottom surface hardness must be examined individually, while evaluating the mechanical properties of resin materials. Soh ${ }^{18,19}$ stated that in order to polymerise a 2 $\mathrm{mm}$ thick resin successfully, the light intensity should at least be $400 \mathrm{~mW} / \mathrm{cm} 2$ and the curing distance should be maximum 3-4 mm from the restoration surface. One difficulty with indirect adhesive restorations is to achieve an adequate degree of polymerization of the resin cement or base material beneath the restoration.

This study evaluated the effect of different curing distances (0, 3 or $6 \mathrm{~mm}$ ), 2 time periods (immediate or after 24 hours), 4 different ceramic materials on the microhardness of dual-cured resin cement (NX3 Nexus Third Generation, Kerr Corporation). The null hypothesis is that the hardness values of resin cement are not affected from different curing distances and veneering materials.

\section{MATERIALS AND METHODS}

One hot-pressed lithium disilicate based ceramic (IPS e.max Press (EP), Ivoclar Vivadent AG, Schaan, Liechtenstein) which is produced in laboratory and three different CAD/CAM blocks (Lava Ultimate (LU), 3M ESPE, St. Paul, MN, USA; IPS e.max CAD (EC), Ivoclar Vivadent AG, Schaan, Liechtenstein; Vita Suprinity (VS), Vita Zahnfabrik, Bad Säckingen, Germany) were investigated in this study. Materials used in the study are shown on Table 1. 
Table 1. The brand names, lot numbers, abbreviations, components and manufacturers of the materials used in the study

\begin{tabular}{|c|c|c|c|c|}
\hline $\begin{array}{l}\text { Brand } \\
\text { Name }\end{array}$ & Lot no & Abbr. & Component & Manufacturer \\
\hline $\begin{array}{l}\text { IPS e.max } \\
\text { Press }\end{array}$ & & EP & Lithium disilicate glass ceramic $\left(\mathrm{LS}_{2}\right)$ & $\begin{array}{l}\text { Ivoclar Vivadent AG, } \\
\text { Schaan, Liechtenstein }\end{array}$ \\
\hline $\begin{array}{l}\text { IPS e.max } \\
\text { CAD }\end{array}$ & T11044 & EC & Lithium disilicate glass ceramic $\left(\mathrm{LS}_{2}\right)$ & $\begin{array}{l}\text { Ivoclar Vivadent AG, } \\
\text { Schaan, Liechtenstein }\end{array}$ \\
\hline $\begin{array}{l}\text { Lava } \\
\text { Ultimate }\end{array}$ & N532098 & LU & $\begin{array}{l}\text { Resin Nano Ceramic } \\
\text { Monomer: Bis-GMA, UDMA, Bis-EMA, } \\
\text { TEGDMA } \\
\mathrm{Filller}_{\mathrm{S}} \mathrm{SiO}_{2}(20 \mathrm{~nm}), \mathrm{ZrO}_{2}(4-11 \mathrm{~nm}) \text {, aggregated } \\
\mathrm{ZrO}_{2} / \mathrm{SiO}_{2} \text { cluster }\left(\mathrm{SiO}_{2}=20 \mathrm{~nm}, \mathrm{ZrO}_{2}=4-11 \mathrm{~nm}\right) \\
\text { aprproximately } \% 80 \text { nanoceramic particles }\end{array}$ & $\begin{array}{l}\text { 3M ESPE, St. Paul, MN, } \\
\text { USA }\end{array}$ \\
\hline $\begin{array}{l}\text { VITA } \\
\text { Suprinity }\end{array}$ & 49342 & vs & $\begin{array}{l}\text { Zirconia-reinforced lithium silicate ceramic } \\
56-64 \% \mathrm{SiO}_{2}, 15-21 \% \mathrm{Li}_{2} \mathrm{O}, 8-12 \% \mathrm{ZrO}_{2}, 3-8 \% \\
\mathrm{P}_{2} \mathrm{O}_{5}, 1-4 \% \mathrm{~K}_{2} \mathrm{O}, 1-4 \% \mathrm{AB}_{2} \mathrm{O}_{3}, 0-4 \% \mathrm{CeO}_{2}\end{array}$ & $\begin{array}{l}\text { Vita Zahnfabrik H. Rauter } \\
\text { GmbH, Bad Săckingen, } \\
\text { Germany }\end{array}$ \\
\hline
\end{tabular}

One rectangular shaped specimen with $12 \mathrm{~mm}$ of width and $14 \mathrm{~mm}$ of length were prepared from each ceramic material. The specimen were cut in $1 \mathrm{~mm}$ thicknesses from CAD/CAM blocks using a low speed diamond saw (Isomet, Buehler, Lake Bluff, IL, USA) under water cooling. EC and VS specimens were crystallized, glazed and LU specimen was polished manually according to the manufacturer's instructions. EP was fabricated in $1 \mathrm{~mm}$ thickness and glazed according to to the manufacturer's instructions.

A caries free, freshly extracted human molar without any restorations was cleaned mechanically and stored in distilled water at room temperature until used for the test. Then it was inserted in a custom made acrylic resin (Meliodent, Heraeus Kulzer, Hanau, Germany) mold. The tooth surface was abraded with a coarse grit diamond rotary cutting instrument $(6856$ L-016 Gebr. Brassler GmbH \& Co. KG, Lemgo, Germany) untill the dentin surface was exposed. The dentin surfaces were levelled to the acrylic resin surface. Then the occlusal surface of the tooth was further abraded with a mechanical grinder (MetkonGripo 2V Grinder Polisher, Metkon Instruments Ltd, Bursa, Turkey) using 600 grit $\mathrm{SiC}$ papers under water cooling for 30 seconds. A translucent strip was placed on the dentin surface. A teflon mold with an opening in the center $(1 \mathrm{~mm}$ thick and $5 \mathrm{~mm}$ in diameter) was used for the application of the dual-cured resin cement (Yellow, NX3 Nexus Third Generation, Kerr Co., Orange, CA) to the dentin surfaces according to the manufacturer's instructions and another strip covered it. On top of the strip, ceramic specimen were placed (Fig. 1).

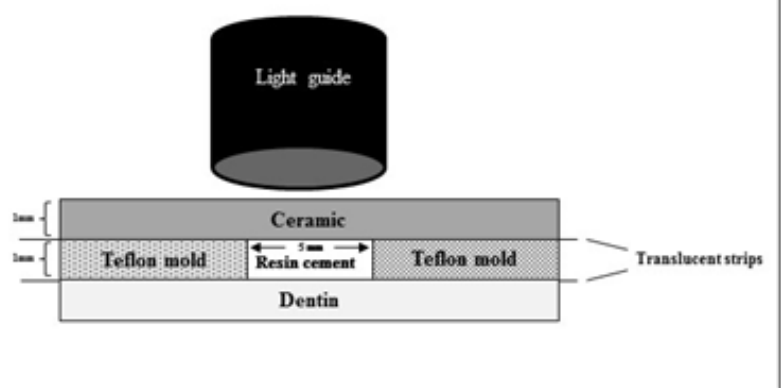

Figure 1. Schematic illustration of specimen preparation.
Groups were separated according to the curing distances $(0,3$ or $6 \mathrm{~mm})$ between the ceramic and the top of the curing tip. To set standard curing distances, 0,3 or $6 \mathrm{~mm}$ thick plastic rings were placed around the opening of the mould. The resin cement was cured by using a high power intensity light emitting diode (LED) unit (Demi Ultra Kerr, Kerr Co., Orange, CA, at a light intensity of 1100 of $\mathrm{mW} / \mathrm{cm} 2$ ) with curing time of 10 seconds according to the manufacturer's instructions. Light intensity was checked before every application with a curing radiometer (SDI Limited, Bayswater, Victoria, Australia). The specimens were prepared for each group ( $n=10)$ (Fig. 2).

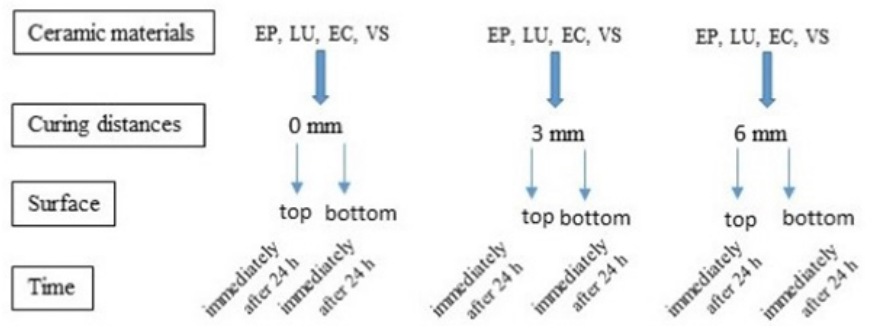

Figure 2. Schematic illustration of the experimental design (EP: IPS e.max Press, LU: Lava Ultimate, EC: IPS e.max CAD, VS: Vita Suprinitiy).

Vickers hardness $(\mathrm{VH})$ values were measured using the microhardness testing machine (Shimadzu Microhardness Tester HMV-2, Shimadzu Corporation, Tokyo, Japan) under $50 \mathrm{~g}$ of loading in 15 seconds. The measurements were made at three points of top and each side of the specimen and the mean values were determined as the $\mathrm{VH}$ values. First measurements took place right after the polymerization, the second measurements were carried from the same specimens after storage in distilled water at $37^{\circ} \mathrm{C}$ in a dark environment for 24 hours. Specimen were stored in light-proof boxes after the polymerization procedure to avoid further exposure to light.

The data were statistically analysed with software (SPSS 18.0 for Windows; IBM Corp., SPSS Inc., Chicago, IL, USA). Repeated Measurements Analysis of Variance (ANOVA) was used to analyse the data (ceramic materials, curing distances, surfaces and measurement times). Bonferroni test was used to perform multiple comparisons $(P<.05)$. Measurement of intensity of transmitted light Light transmission by the specimens were determined by placing each to the internal part of radiometer (SDI Limited) and irradiating the specimen for 10 seconds. The LED radiometer is designed to measure the energy between 400 and $525 \mathrm{~nm}$, and gives readings from 0 to $2100 \mathrm{~mW} /$ $\mathrm{cm} 2$. Over the irradiation period of 10 seconds, the value of the transmitted light was recorded. The instrument measured the transmitted light through each specimen or without any specimens in $\mathrm{mW} / \mathrm{cm} 2$ received by the radiometer detector. The average of 3 readings are showed in Fig 3. 


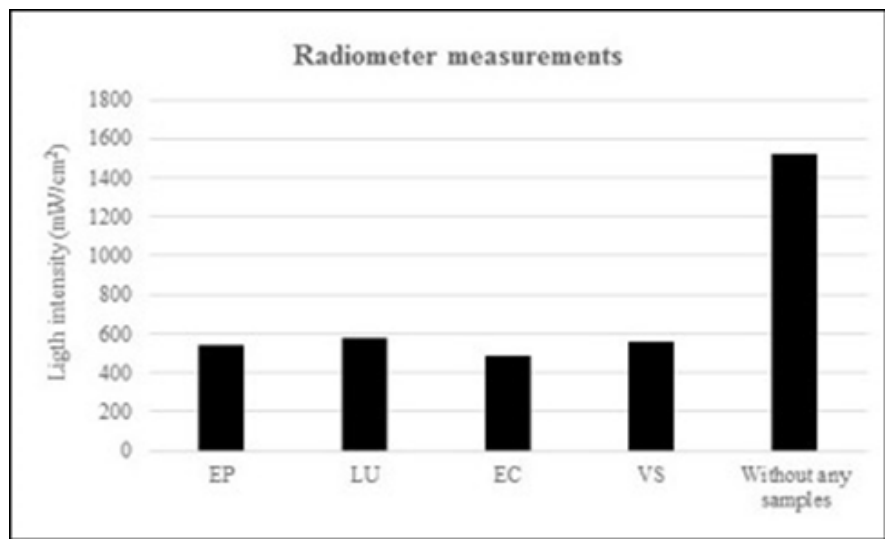

Figure 3. Radiometer measurements of polymerization light intensity $(\mathrm{mW} / \mathrm{cm} 2)$ through ceramic materials tested and without any samples. (EP: IPS e.max Press, LU: Lava Ultimate, EC: IPS e.max CAD, VS: Vita Suprinitiy).

\section{RESULTS}

Mean VH values and standard deviations for the top and bottom surfaces of dual-cured resin cement polymerized under ceramic materials are given in Table 2 and 3.

Table 2: The mean hardness values of the top surfaces, standard deviations and differences among the groups

\begin{tabular}{|c|c|c|c|c|c|c|}
\hline Materials & $\begin{array}{l}0 \mathrm{mm-}- \\
\text { immediately } \\
\text { (Mean } \pm \mathrm{SD})\end{array}$ & $\begin{array}{l}0 \mathrm{~mm} \text {-after } 24 \mathrm{~h} \\
\text { (Mean } \pm \text { SD) }\end{array}$ & $\begin{array}{l}3 \mathrm{~mm}- \\
\text { immediately } \\
\text { (Mcan } \pm \text { SD) }\end{array}$ & $\begin{array}{l}3 \mathrm{~mm} \text {-after } 24 \mathrm{~h} \\
\text { (MeantSD) }\end{array}$ & $\begin{array}{l}6 \mathrm{~mm}- \\
\text { immediately } \\
\text { (Mean } \pm \mathrm{SD})\end{array}$ & 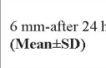 \\
\hline EP & $17.03+4.45^{A a}$ & $29.15+5.57^{\complement \mathrm{a}}$ & $11.03+1.33^{\text {Е }}$ & $24.97+3.46^{\text {cab }}$ & $8.06+1.49^{\mathrm{ka}}$ & $25.05+4.5^{\mathrm{ch}}$ \\
\hline $\mathbf{L U}$ & $28.36 \pm 5.11^{1 A b}$ & $38.84 \pm 4.83^{\text {cb }}$ & $20.62 \pm 2.52^{2 \mathrm{Ab}}$ & $27.51 \pm 3.65^{\text {Da }}$ & $11.09 \pm 5.62^{\mathrm{Ba}}$ & $25.78+3.29^{\mathrm{Db}}$ \\
\hline EC & $18.70 \pm 2.02^{\Lambda a}$ & $23.53 \pm 0.64^{c a}$ & $16.85 \pm 0.74^{A C}$ & $20.93 \pm 1.68^{\mathrm{Ib}}$ & $12.66 \pm 1.1^{\mathrm{Ba}}$ & $19.63 \pm 0.88^{\mathrm{DCa}}$ \\
\hline vs & $17.49 \pm 2.72^{\mathrm{Aa}}$ & $24.02 \pm 0.86^{\mathrm{ca}}$ & $16.41 \pm 1.72^{\mathrm{ABC}}$ & $21.65 \pm 1.18^{56}$ & $13.29+1.78^{89}$ & $19.01 \pm 1.33^{\mathrm{Ec}}$ \\
\hline
\end{tabular}

Table 3: The mean hardness values of the bottom surfaces, standard deviations and differences among the groups

\begin{tabular}{|c|c|c|c|c|c|c|}
\hline Materials & $\begin{array}{l}0 \text { mm- } \\
\text { immediately } \\
\text { (Mean } \pm \text { SD) }\end{array}$ & $\begin{array}{l}0 \mathrm{~mm} \text {-after } 24 \mathrm{~h} \\
\text { (MeantSD) }\end{array}$ & $\begin{array}{l}3 \mathrm{~mm}- \\
\text { immediately } \\
\text { (Mean } \pm \text { SD) }\end{array}$ & $\begin{array}{l}3 \mathrm{~mm} \text {-after } 24 \mathrm{~h} \\
\text { (Mean } \pm \text { SD) }\end{array}$ & $\begin{array}{l}6 \mathrm{~mm}- \\
\text { immediately } \\
\text { (MeantSD) }\end{array}$ & $\begin{array}{l}6 \text { mm-after 24 } \\
\text { (Mean士SD) }\end{array}$ \\
\hline EP & $8.98+2.69^{\wedge a}$ & \begin{tabular}{|l|}
$21.69+4.67^{84}$ \\
\end{tabular} & $7.36+1.17^{12}$ & \begin{tabular}{|c|}
$17.86+3.09^{98}$ \\
\end{tabular} & $5.78+1.10^{\wedge x}$ & $23.40 \pm 4.29^{9^{5 i}}$ \\
\hline $\mathbf{L U}$ & $11.84+1.99^{9 a}$ & \begin{tabular}{|c|}
$21.77 \pm 3.69^{\mathrm{Ba}}$ \\
\end{tabular} & $11.33+2.70^{0 \mathrm{aa}}$ & \begin{tabular}{|l}
$17.97 \pm 2.90^{\mathrm{BCa}}$ \\
\end{tabular} & $8.74+1.06^{\mathrm{Ab}}$ & $13.03+1.34^{\mathrm{cb}}$ \\
\hline EC & $12.34 \pm 2.42^{\mathrm{Aag}}$ & \begin{tabular}{|l}
$16.77 \pm 0.42^{\mathrm{Ba}}$ \\
\end{tabular} & $10.68+1.22^{1 \mathrm{Aa}}$ & \begin{tabular}{|l}
$12.89 \pm 0.99^{\mathrm{cb}}$ \\
\end{tabular} & $7.89 \pm 1.79^{A \mathrm{Ab}}$ & $10.39 \pm 1.01^{106}$ \\
\hline vs & $10.97 \pm 1.36^{\mathrm{Aa}}$ & $15.54 \pm 0.70^{\mathrm{Bb}}$ & $11.53 \pm 3.00^{9^{\mathrm{Aa}}}$ & $14.38 \pm 2.24^{\mathrm{BCab}}$ & $9.45 \pm 2.26^{\Delta b}$ & $11.27 \pm 2.14^{\mathrm{cb}}$ \\
\hline
\end{tabular}

Results of ANOVA revealed that there are no statistically significant differences $(p=0.139)$ among the factors investigated (ceramic materials, curing distances, measuring time and surfaces).

It is shown that ceramic materials have an effect on the surface hardness of the resin cement. The resin cements under the LU specimens have significantly higher VH values compared to EP, EC and VS groups ( $p<0.001) .0 \mathrm{~mm}$ distance groups have significantly higher $\mathrm{VH}$ values and there are significant differences among all curing distances $(0,3,6 \mathrm{~mm})(p<0.001)$. The VH values were significantly higher after 24 hours than immediate measurement $(p<0.001)$.

Comparing the top and bottom surfaces of the polymerized resin cements, the bottom surfaces have significantly lower $\mathrm{VH}$ values for all ceramic groups $(p<0.001)$. For the top surfaces, the lowest $\mathrm{VH}$ value was measured immediately after the polymerization in the EP group with $6 \mathrm{~mm}$ distance $(8.06 \pm 1.49 \mathrm{VH})$ and the highest $\mathrm{VH}$ value was recorded after 24 hours in LU group with $0 \mathrm{~mm}$ distance $(38.84 \pm 4.83 \mathrm{VH})$. For the bottom surfaces, the lowest VH value was recorded immediately after the polymerization in EP group with distance $6 \mathrm{~mm}(5.78 \pm 1.10 \mathrm{VH})$ and the highest $\mathrm{VH}$ value was measured after 24 hours in the EP group with $6 \mathrm{~mm}$ distance $(23.40 \pm 4.29 \mathrm{VH})$.

The measurements after 24 hours showed the lowest surface hardness values in EC group with $6 \mathrm{~mm}$ distance $(10.39 \pm 1.01 \mathrm{VH})$ for bottom surfaces and the highest value in LU group with $0 \mathrm{~mm}(38.84 \pm 4.83 \mathrm{VH})$ for the top surfaces.

When the light transmission was evaluated, LU showed the highest light transmittance $(580 \mathrm{~mW} / \mathrm{cm} 2)$ where as EC group showed the lowest $(485 \mathrm{~mW} / \mathrm{cm} 2)$.

\section{DISCUSSION}

The hypothesis of the present study was that the hardness values of resin cement is not affected from different curing distances and veneering materials. However, the study concluded that curing distances and veneering materials effect $\mathrm{VH}$ value. Therefore, the null hypothesis was rejected.

Lately the clinicians and patients prefer full ceramic restorations because of their advanced aesthetic properties. The colour and translucency of the full ceramic restorations have a great effect on the diffuse and specular reflection of light, therefore they are significant determinants of the final aesthetic outcome. ${ }^{20}$ Dual cure cements are recommended for the cementation of the full ceramic restorations because they are able to overcome the problems of decreased light intensity and they ensure sufficient polymerization at the base area of the restoration where light intensity is very limited. An incomplete polymerization of the luting cement causes problems in ceramic restorations. In order to achieve the maximum physical properties of resin cements, the conversion rate should be as high as possible. ${ }^{21-23}$ In the current study; the effect of different curing tip-restoration distances, type of restoration and time periods on the hardness of the dual-cure resin cement were investigated.

The effectiveness of curing can be evaluated directly or indirectly: direct methods, such as infrared spectroscopy, are complicated, expensive and time-consuming. Visual, scraping and hardness testing are the indirect methods. Because of its simplicity and good correlation with the infrared spectroscopy, hardness testing is preferred by many previous studies. ${ }^{24,25}$ According to Uhl ${ }^{26}$, Knoop and Vickers hardness tests are more accurate in measuring the degree of polymerization compared to tests with a penetrometer showing the depth of cure. Sufficient polymerization of resin cements can be a challenge under indirect restorations 14. In this study the Vickers hardness test to measure the hardness of the resin cements was used.

To make sure of the complete polymerization through 
the whole resin cement, both the light cured side and the bottom side of the specimen were evaluated. Polymerization limitations effecting the microhardness of the resin cement is a very important issue regarding the clinical success of a restoration. According to some studies, the top surfaces of the resin cements are significantly harder than the bottom surfaces. ${ }^{14,18,27-29}$ This difference may depend on to the decrease of light intensity occurring when light passes through the filler particles and resin matrix. 30 Also light intensity is less in inner parts compared to the surface areas because it is absorbed and scattered by the composite mass. ${ }^{29}$ Pires et $a l^{31}$ states that the initial light application immediately starts the polymerization of the light sensitive molecules in the surface which blocks the light from reaching the deeper areas. The results of the current study have showed similar results with the previous ones.

The translucency of ceramic restorations is dependent on the light transmission and polymerization degree of the luting agent. ${ }^{32,33}$ The translucency of veneer restorations may vary depending on compositions and fabrication methods. These differences affect the polymerization of dual-cured resin cements. ${ }^{34}$ For ceramic restorations, many factors affect the light transmission. Similarly, in resin restorations factors such as thickness, resin matrix composition, filler particles, aging and polymerization might affect the light transmission. ${ }^{35}$ According to the results of the current study, the resin nanoceramic material (LU) presented the highest light transmission, followed by the zirconia reinforced lithium silicate (VS) and the lithium disilicate glass ceramics (EP, EC). Because of the filler amount, size and character, resin based CAD/CAM material presented the highest light transmission. ${ }^{35-37}$ The resin cements under the LU specimens present higher surface hardness values compared to the other restoration materials. This situation can be explained by the differences present in the microstructures of the ceramic materials used in this study.

According to some studies, the micro hardness values of resin material is directly related with the distance of the tip of LED unit. ${ }^{38}$ Ersoz et a ${ }^{29}$ states that 0 and $3 \mathrm{~mm}$ distances show significant difference, however $6 \mathrm{~mm}$ and 9 $\mathrm{mm}$ distances showed lower hardness values. In the current study, 0, 3 or $6 \mathrm{~mm}$ distances were compared and there were statistically significant differences among the distances tested as well.

Dual-cured resin cements are suggested for luting ceramic restorations because of their ability to guarantee efficient polymerization even with reduced light intensities. ${ }^{39}$ Peutzfeldt ${ }^{40}$ stated that; in order to obtain the best physical properties in dual-cured cements, light polymerization should be used. Chemical curing should not be relied on alone for polymerization. In accordance with the current study, the results of a previous study ${ }^{41}$ showed that, dual polymerization with immediate measurements obtained the lowest degree of cure results, while measurements 24 hours after the dual polymerization obtained the highest. Materials with high transmittance allows higher irradiance on the cement surface which increases the conversion degree and the mechanical properties. Further investigation is needed with differrent ceramic materials, curing units and luting materials. The present study has several limitations, making it difficult to compare results directly with clinical studies. Resin cement thickness tested in the current study was $2 \mathrm{~mm}$, which is $25-150 \mu \mathrm{m}$ in the clinical situations. ${ }^{42}$ Future investigations should be performed using different resin cement thicknesses for greater clinical relevance. Another limitation of the present study was that it was performed under in vitro conditions, but the results still provide guidance for clinicians. Other adhesion tests or mechanical tests can be used to confirm the results. Due to the lack of aging mechanism and varying resin cement and ceramic material thickness, the study model does not accurately simulate the clinical performance of an aesthetic indirect restoration.

\section{CONCLUSION}

Within the limitations of this in vitro study, the following conclusions could be drawn:

1. When cementing all ceramic restorations with resin cements, the light source should be as close as possible to the restoration surface. Because the polymerization of resin cements are adversely affected by the curing distance.

2. The polymerization reaction of dual-cure resin cements continue after the cementation.

3. Among the tested ceramic materials, the resin nanoceramic (LU) restorations present the highest light transmission. Consequently, the most successful polymerization of the resin cements can be achieved under LU restorations.

\section{REFERENCES}

1. Andreatta Filho OD, Bottino MA, Nishioka RS, Valandro $L F$, Leite FP. Effect of thermocycling on the bond strength of a glass-infiltrated ceramic and a resin luting cement. J Appl Oral Sci 2003; 11: 61-67.

2. Fasbinder DJ. Computerized technology for restorative dentistry. Am J Dent 2013; 26: 115-120.

3. Göncü Başaran E, Ayna E, Vallittu PK, Lassila LV. Load-bearing of handmade and computer-aided design-computer-aided manufacturing-fabricated tree-unit fixed dental prostheses of particulate filler composite. Acta Odontol Scand 2011; 69: 144-150.

4. Lauvahutanon S. Mechanical properties of composite resin blocks for CAD/CAM. Dent Mater J 2014; 33: 705- 
710.

5. Fuster-Torres MA1, Albalat-Estela S, Alcañiz-Raya M, Peñarrocha-Diago M. CAD/CAM dental systems in implant dentistry: update. Med Oral Patol Oral Cir Bucal 2009; 14: 141-145.

6. Davidowitz G, Kotick PG. The use of CAD/CAM in dentistry. Dent Clin North Am 2011; 55:559-570.

7. ÖGiordano R. Materials for chairside CAD/CAM-produced restorations. J Am Dent Assoc 2006; 137: 14-21.

8. Chen C, Trindade FZ, de Jager N, Kleverlaan CJ, Feilzer AJ. The fracture resistance of a CAD/CAM Resin Nano Ceramic (RNC) and a CAD ceramic at different thicknesses. Dent Mater 2014; 30: 954-962.

9. Mörmann WH, Stawarczyk B, Ender A, Sener B, Attin T, Mehl A. Wear characteristics of current aesthetic dental restorative CAD/CAM materials: two-body wear, gloss retention, roughness and Martens hardness. J Mech Behav Biomed Mater 2013;20:113-25.

10. Kanat $B$, . Effect of various veneering techniques on mechanical strength of computer-controlled zirconia framework designs. J Prosthodont 2014; 23: 445-455.

11. Uctasli S, Hasanreisoglu U, Wilson HJ. The attenuation of radiation by porcelain and its effect on polymerization of resin cements. J Oral Rehabil 1994; 21: 565-575.

12. Pazin MC, . Effects of ceramic thickness and curing unit on light transmission through leucite-reinforced material and polymerization of dual-cured luting agent. J Oral Sci 2008; 50: 131-136.

13. Neumann MG1, Schmitt CC, Ferreira GC, Corrêa IC. The initiating radical yields and the efficiency of polymerization for various dental photoinitiators excited by different light curing units. Dent Mater 2006; 22: 576-584.

14. Santos MJ, Passos SP, da Encarnação MO, Santos GC Jr, Bottino MA. Hardening of a dual-cure resin cement using QTH and LED curing units. J Appl Oral Sci 2010; 18: 110-115.

15. Bayindir $Y Z$, Yildiz M, Bayindir F. The effect of "softstart polymerization" on surface hardness of two packable composites. Dent Mater J 2003; 22: 610-616.

16. Deb S, Sehmi H. A comparative study of the properties of dental resin composites polymerized with plasma and halogen light. Dent Mater 2003;19:517-22.

17. Price RB, Felix CA, Andreou P. Evaluation of a second-generation LED curing light. J Can Dent Assoc 2003;69:666

18. Soh MS, Yap AU, Siow KS. Effectiveness of composite cure associated with different curing modes of led lights. Oper Dent 2003a; 28: 371-377.

19. Soh MS, Yap AU, Siow KS. The effectiveness of cure of LED and halogen curing lights at varying cavity depths. Oper Dent 2003b; 28: 707-715.

20. Blatz MB, Sadan A, Kern M. Resin-ceramic bonding: a review of the literature. J Prosthet Dent 2003; 89: 268-
274.

21. Cekic-Nagas I, Ergun G, Vallittu PK, Lassila LV. Influence of polymerization mode on degree of conversion and micropush-out bond strength of resin core systems using different adhesive systems. Dent Mater J 2008; 27: 376-385.

22. Reges RV, . In-depth polymerization of dual-cured resin cement assessed by hardness. J Biomater Appl 2008; 23: 85-96.

23. Jung $\mathrm{H}$, . Polymerization efficiency of different photocuring units through ceramic discs. Oper Dent 2006; 31: 68-77.

24. Kuguimiya RN, . Influence of light-curing units and restorative materials on the micro hardness of resin cements. Indian J Dent Res 2010; 21: 49-53.

25. Fennis WM, Ray NJ, Creugers NH, Kreulen CM. Microhardness of resin composite materials light-cured through fiber reinforced composite. Dent Mater 2009; 25: 947-951.

26. Uhl A, Mills RW, Jandt KD. Photoinitiator dependent composite depth of cure and Knoop hardness with halogen and LED light curing units. Biomaterials 2003; 24: 1787-1795.

27. Cavalcante LM, Peris AR, Amaral CM, Ambrosano GMB, Pimenta LA. Influence of polymerization technique on microleakage and microhardness of composite restoration. Oper Dent 2003; 28: 200-206.

28. Sharkey S, Ray N, Burke F, Ziada H, Hannigan A. Surface hardness of light-activated resin composites cured by two different visible-light sources: an in vitro study. Quinttessence Int 2001; 32: 401-405.

29. Santos GC, El-Mowafy O, Rubo JH, Santos MJ. Hardening of Dual-Cure Resin Cements Cured with QTH and LED Curing Units. J Can Dent Assoc 2004; 70: 346-353.

30. Ruyter IE, Qysaed H. Conversion in different depths of ultraviolet and visible light activated composite resin materials. Acta Odontol Scand 1982; 40: 179-1792.

31. Pires JA, Cvitko E, Denehy GE, Swift EJ Jr. Effects of curing tip distance on light intensity and composite resin microhardness. Quintessence Int 1993; 24: 517-521.

32. Ilie N, Hickel R. Correlation between ceramics translucency and polymerization efficiency through ceramics. Dent Mater 2008; 24: 908-914.

33. Rasetto $F H$, Driscoll CF, Prestipino $V$, Masri R, von Fraunhofer JA. Light transmission through all-ceramic dental materials: a pilot study. J Prosthet Dent 2004; 91 : 441-446.

34. Öztürk E, . Effect of resin shades on opacity of ceramic veneers and polymerization efficiency through ceramics. J Dent 2013; 41: 8-14.

35. Azzopardi N, Moharamzadeh K, Wood DJ, Martin N, van Noort R. Effect of resin matrix composition on the translucency of experimental dental composite resins. 
Dent Mater 2009; 25: 1564-1568.

36. del Mar Pérez M, Saleh A, Pulgar R, Paravina RD. Light polymerization-dependent changes in color and translucency of resin composites. Am J Dent 2009; 22: 97-101.

37. dos Santos GB, Alto RV, Filho HR, da Silva EM, Fellows CE. Light transmission on dental resin composites. Dent Mater 2008; 24: 571-576.

38. Bennett AW, Watts DC. Performance of two blue light-emitting-diode dental light curing units with distance and irradiation-time. Dent Mater 2004; 20: 72-79.

39. Krämer N, Lohbauer U, Frankenberger R. Adhesive luting of indirect restorations. Am J Dent 2000; 13: 60-76. 40. Peutzfeldt A. Dual-cure resin cements: in vitro wear and effect of quantity of remaining double bonds, filler volume, and light curing. Acta Odontol Scand 1995; 53: 29-34.

41. Ozyesil AG, Usumez A, Gunduz B. The efficiency of different light sources to polymerize composite beneath a simulated ceramic restoration. J Prosthet Dent 2004; 91: 151-157.

42. Anusavice KJ, Phillips RW. Phillips' science of dental materials. 11th ed. St. Louis, Mo: Saunders; 2003. p. 467468. 
